\title{
CDC34 wt Allele
}

National Cancer Institute

\section{Source}

National Cancer Institute. CDC34 wt Allele. NCI Thesaurus. Code C101301.

Human CDC34 wild-type allele is located in the vicinity of 19p13.3 and is approximately 10 $\mathrm{kb}$ in length. This allele, which encodes ubiquitin-conjug ating enzyme E2 R1 protein, is involved in the modification of ubiquitin. 